\title{
AdDING ROOMS ONTO A House We Love: CENTRAL BANKING AFTER THE GLOBAL FINANCIAL CRISIS
}

\author{
Juliet Johnson, Vincent Arel-Bundock, Vladislav Portniaguine ${ }^{1}$
}

Forthcoming in Public Administration

2018-10-17

\begin{abstract}
This article examines the extent to which central bankers have been willing and able to rethink their beliefs about monetary policy in the wake of the Global Financial Crisis. We show that despite the upheaval, the core pre-crisis monetary policy paradigm remains relatively intact: central bankers believe that they should primarily pursue price stability through targeting low inflation in a transparent manner, and that they need operational independence to achieve this goal. In a bid to address post-crisis conditions and maintain their credibility, however, central bankers have also layered new elements onto the old core. We document both the resilience of pre-crisis beliefs and the process of layering using computer-assisted text analysis and qualitative analysis of 13,586 speeches given between 1997 and 2017 by central bankers from around the world.
\end{abstract}

${ }^{1}$ Corresponding author: juliet.johnson@mcgill.ca We thank Manuella Moschella, Sam McPhilemy, Andrew Baker, Denis Saint-Martin, all of the participants in the 2016 ECPR workshop and 2017 Scuola Normale Superiore workshop on central banking, two anonymous reviewers, and the Editor of Public Administration. We acknowledge the financial support of the Social Sciences and Humanities Research Council of Canada. 
"It still feels to me like we are adding various rooms onto a house we love, rather than creating a new, elegant, and coherent structure."

- Stephen Poloz, Bank of Canada, 2015 (r150226a)

Central bankers, scholars, and politicians alike have observed the multiple ways in which the global financial crisis of 2007-08 has reshaped the theory and practice of central banking. In the wake of the crisis, central bankers faced fundamental challenges to their previously dominant, widely shared beliefs and practices. A shock of this magnitude naturally spurs a desire to understand why it happened and to prevent recurrence (Bennett \& Howlett, 1992). At the same time, as Rose $(1991,3)$ puts it, "searching for fresh knowledge is not normal." The costs of information acquisition, the uncertainty associated with policy change, the embeddedness of routine practices, and the appeal of the status quo can all hinder change in public agencies. This article examines central bank learning in monetary policy, investigating the extent to which central bankers have been willing and able to rethink their pre-crisis monetary policy paradigm.

To assess the lessons that central bankers have learned from the crisis, we take them at their word. That is, we draw on the Bank for International Settlements (BIS) database of 13,586 speeches given by central bankers worldwide from 1997-2017 (Figure 1) to conduct both quantitative and qualitative text analysis. ${ }^{2}$ It is a rich trove of data, one that has increasingly been mined by scholars using automated text analytic techniques (Bennani \& Neuenkirch, 2017; Fontan, Claveau, \& Dietsch, 2016; van Esch \& de Jong, 2017). This line of work dovetails with a broader interest by academics and central bankers in using quantitative content analysis to study central bank-related themes (Bholat, Hansen, Santos, \& Schonhardt-Bailey, 2015; Golub, Kaya, \& Reay, 2015; Moschella \& Pinto, 2019; Schonhardt-Bailey, 2013).

Overall, we find that crisis-induced challenges did not shake central bankers' confidence in the core aspects of their original monetary policy paradigm. Instead, they have been layering new elements onto the old, in a process of incremental change aimed at preserving the hard-won credibility of central banks as competent public agencies.

\section{The Pre-Crisis CONSENSUS ON MONETARy Policy}

Before the global financial crisis, central bankers had reached broad international agreement on a monetary policy paradigm. Hall (1993) defines a policy paradigm as "a

2 We cite these speeches by name, country, year, and BIS database reference number in the text (e.g., Poloz, Canada, 2015, r150226a). Each speech can be accessed directly from the BIS website by searching the reference number at http://www.bis.org/list/cbspeeches/. A plurality of the speakers are from Europe, followed in prevalence by East Asia/Pacific and North America (see Figure 1). 
framework of ideas and standards that specifies not only the goals of policy and the kinds of instruments that can be used to attain them, but also the very nature of the problems they are meant to be addressing" (279). As Goodfriend described it in "How the World Achieved Consensus on Monetary Policy":

The modern theoretical consensus -- known alternatively as the New Neoclassical Synthesis or the New Keynesian model of monetary policy -- reinforces key advances: the priority for price stability; the targeting of core rather than headline inflation; the importance of credibility for low inflation; and preemptive interest rate policy supported by transparent objectives and procedures. (Goodfriend, 2007, 48).

Central bankers had identified the key problem for monetary policy as the natural tendency of governments to stoke inflation for short-term political advantage at the expense of longterm macroeconomic stability and growth (the so-called time-inconsistency problem). Central bankers' primary goal should thus be to pursue and maintain price stability, which refers to maintaining a low, stable rate of inflation over the medium term. To do so in a credible manner, central banks needed operational independence from their governments. Independent central bankers would ideally pursue the goal of price stability through transparent interest-rate policy guided by inflation targeting, which refers to publicly announcing an inflation rate (most commonly 2\%) that the central bank would aim to maintain over the medium term.

While not all central banks could fully operationalize this monetary policy paradigm, the pre-crisis central banking community recognized it as best practice (Blinder, 2008; Blyth \& Matthijs, 2017; Braun, 2018). ${ }^{3}$ As the BIS's Claudio Borio (2011) put it in a retrospective on the era, "the prevailing pre-crisis consensus had gravitated towards a 'narrow' view of central banking, heavily focused on price stability and supported by a belief in the self-equilibrating properties of the economy." Research on the relationship between central bank independence and inflation proliferated, the new European Central Bank (ECB) was given both significant independence and a narrow price stability mandate, and the central banking community spread its monetary policy paradigm to the newly postcommunist world (Johnson, 2016).

\footnotetext{
${ }^{3}$ Braun (2018) refers to this consensus supporting "monetary inflation targeting underpinned by the new neoclassical synthesis" as a governability paradigm, which is "established when a political consensus on macroeconomic policies is reinforced by an academic consensus on macroeconomic theories." This paradigm was embedded within what Blyth and Matthijs (2017) call the prevailing pre-crisis "global macroeconomic regime."
} 
Figure 1: Speeches per Year by Region, 1997-2017 (BIS database)

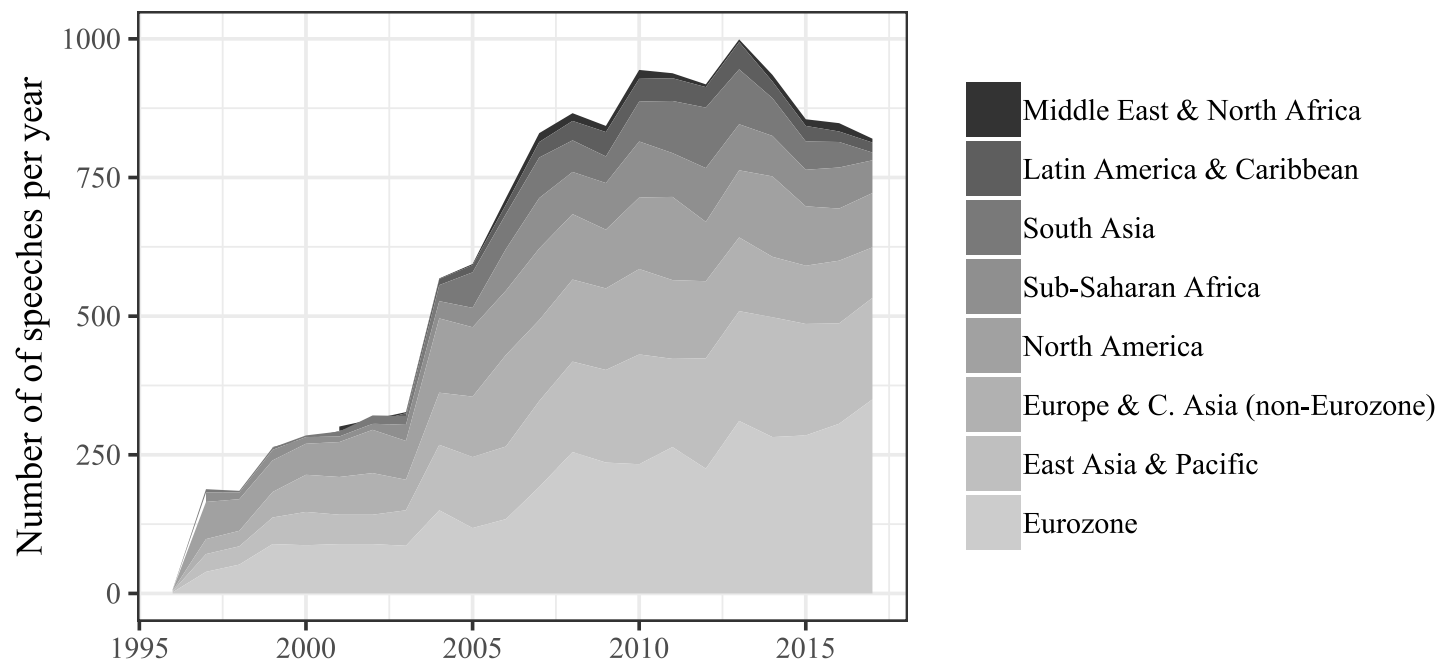

\section{THE SHOCK OF THE GLOBAL FinANCIAL CRISIS}

The global financial crisis stunned the central banking community. Unlike the 1997 Asian financial crisis, this one arose from the heart of the international monetary order - the United States. It demonstrated that independent central banks tightly focused on maintaining price stability could not ensure domestic or international financial stability. Many critics alleged that this narrow focus had in fact helped to spark the crisis, by causing complacency in financial markets and by downplaying the importance of regulation, supervision, and systemic threats (for an overview, see Davies \& Green, 2010). Central banks found that they could no longer reliably deliver price stability, and had new problems and responsibilities thrust upon them (Balls, 2016). The eurozone faced sequential crises, as the European Central Bank's initially rigid adherence to the prevailing monetary policy paradigm after the 2007-08 global crisis contributed to the outbreak of the European sovereign debt crisis in 2010. As a result, the pre-crisis monetary policy paradigm came into question in academic and policy circles around the world.

Should we have expected central bankers to learn new monetary policy lessons from the global financial crisis, even if those lessons challenged their pre-crisis policy paradigm? Crises are often described as critical junctures that open windows of opportunity for fundamental transformations that might otherwise be difficult, impossible, or even unthinkable (Capoccia \& Kelemen, 2007; Collier \& Collier, 2002). Rose (1993) notes that change-oriented lesson-drawing requires dissatisfaction with the status quo, and there is no question that the global financial crisis engendered such dissatisfaction among central bankers. 
But, as Stern (1997) observes, research on crisis learning reveals that although crises can potentially spur such dramatic learning processes, they can also have the opposite effect, inspiring defensiveness, "threat rigidity," and a retreat to the status quo. For example, Stern and Sundelius (1997) show that when faced with crisis in 1992, the Swedish central bank responded by becoming even more rigid in its beliefs. Boin and t'Hart (2003) also note that the pressure to restore normalcy is often overwhelming in the immediate aftermath of crises, making crisis learning a long and laborious process. Moreover, monetary policy is central bankers' raison d'être, so one might expect more resistance to ideational change in this issue-area than in others. For example, Baker's (2015) exploration of central banking in post-crisis Britain finds significantly more "ideational stickiness" in macroeconomic policy than in financial regulation.

Compounding the difficulties, central bankers comprise a relatively small transnational expert community. This community has traditionally enjoyed status as what Dunlop and Radaelli (2013) call a "socially certified actor," meaning that key lesson-drawing dialogues and processes are likely to occur primarily within that sub-system rather than through engagement with external actors and perspectives (Broome \& Seabrooke, 2015; Johnson, 2016; Seabrooke \& Tsingou, 2014). Such constrained sub-system deliberations can result in a slower and more incremental learning and change process, even in the face of crisis. Central bankers have regularly been accused of innovation-stifling groupthink (Boettke \& Smith, 2015; Buiter, 2006; Johnson, 2016), and have themselves admitted groupthink and confirmation bias to be a problem in their profession (Haldane, UK, 2014, r141119a; Wilkins, Canada, 2015, r151222a; Mohan, 2013). Groupthink and a bias towards incrementalism in insulated bureaucracies could make it especially tempting for central bankers to add onto the profession's defining monetary policy paradigm in Ptolemaic style, rather than overturn it in a Copernican revolution.

Given these cross-cutting pressures for stability and change, we follow van Esch (2014) in seeing change as a "spectrum rather than an either/or category"; it can involve the reversal, reduction, reinforcement, and/or stability of the ideas comprising the pre-crisis monetary policy paradigm. In doing so, we identify two general trends. First, as crisislearning research would predict, fundamental beliefs are the most resistant to change (Boin, t Hart, \& McConnell, 2009; Sabatier, 1998). Central bankers appear to be relatively more willing to entertain challenges to their paradigm's policy instruments than to its goals or underlying assumptions about the way the world works. Second, we identify layering as a key post-crisis change mechanism (cf Krampf, 2016 on layering and the ECB). Streeck and Thelen (2005) understand layering as a process through which new ideas and practices accrete on top of old ones instead of displacing them. Layering allows policymakers to acknowledge crisis and adapt to new challenges without jettisoning their previous policy paradigm. Over time, this can result in what Princen and van Esch (2016) refer to as a "moving paradigmatic core," meaning a gradual adaptation or expansion of the original paradigm rather than its rapid replacement with a clear alternative. 


\section{DATA AND METHODOLOGY}

To identify patterns of continuity and change in central bankers' views on monetary policy, we study a corpus of 13,586 speeches given by central bankers around the world between January 1997 and December 2017 (Bank for International Settlements, 2018). ${ }^{4}$ We use three complementary methods to analyze those speeches: word counts, topic modeling, and qualitative content analysis.

The simplest way to study the prevalence of certain themes and ideas in a very large body of text is to use word counts. To do this, we define a "dictionary" of relevant words and phrases, and then instruct a computer to search for those expressions in all the speeches. To build our dictionary, we identified 997 speeches that explicitly discussed at least one lesson learned from the global financial crisis. This involved searching for speeches that included both the words "crisis" and "lesson", and then manually culling the false positives. We used a random sample of these speeches from each year to build a dictionary of 75 key words and phrases commonly used when central bankers discuss the global financial crisis. We then counted the number of times that each of the 75 keywords appears in each speech. Finally, we used locally-weighted regression to plot the prevalence of each keyword in central bankers' speeches over time. In this article, we discuss the subset of keywords that specifically addresses monetary policy.

This word count approach is very useful, but the results it produces are sensitive to the composition of the dictionary. Indeed, the results' credibility necessarily depends on our ability to pre-specify all of the relevant keywords and phrases. The analysis may thus suffer from important blind spots if some themes were missed in the dictionary-building process, or if central bankers use different terminology to discuss similar topics.

To circumvent this problem, we supplement the word count analysis with a second computer-assisted method: topic modeling. In a nutshell, the idea is to use a statistical model to inductively identify the main topics discussed in the corpus, as well as the words most associated with each topic. Topics are groups of words that commonly appear together in close proximity. For example, one of the topics that our model detected in central bankers' speeches relates to "Banking Supervision", a topic composed of the cooccurring word stems "supervis", "prudenti", "regul", and "bank". For any given speech, the topic model can measure the share of words which belong to the "Banking Supervision" topic, the "Macroprudential" topic, the "Central Bank Independence" topic, etc. This allows us to track trends in the importance of various topics over time across all speeches. Interested readers can find an accessible introduction to topic modeling in Grimmer and Stewart (2013). What is most important, for our purposes, is that topic modeling belongs to the category of "unsupervised" text analysis techniques, which means that it does not require

\footnotetext{
${ }^{4}$ Our quantitative text analyses use all the central bankers' speeches archived on the BIS website at the time of data collection.
} 
us to impose a strict list of relevant words or topics ex ante. Therefore, this model acts as a key robustness check for our dictionary-based word count analysis. ${ }^{5}$

While revealing, these quantitative techniques can only tell us how often central bankers discussed key words, phrases, and themes. They do not tell us what bankers say about those topics. Our third empirical strategy is to deploy qualitative analysis to identify the specific lessons central bankers said they had learned from the crisis. We used MaxQDA, a software package for qualitative analysis, to code the segments of the 997 "crisis lesson" speeches containing our keywords. We supplemented this analysis with close readings of a subset of 71 speeches devoted entirely to the lessons of the global financial crisis (speeches whose titles included "lessons" or "learning" from the crisis). This qualitative analysis enables us to discuss not only the relative frequency with which central bankers have used particular words and phrases when discussing the crisis, but also the meaning and context of that speech.

It is important to recognize that central bankers do engage in strategic speech, which means that we cannot assume that any one speaker's public statements perfectly reflect his or her private beliefs. However, political psychologists with access to political leaders' speeches and private notes have found surprising congruence between public and private speech (Dyson \& Raleigh, 2014; Renshon, 2009). Researchers have relied upon public speeches to make "cognitive maps" of individual central bankers' beliefs and their evolution over time (Bennani, 2015; van Esch \& de Jong, 2013), and central bankers themselves claim such congruence (Bennani \& Neuenkirch, 2017; Bernanke, 2015; Rajan, 2017). Moreover, as our primary interest is in broad ideational trends in the central banking community, it seems reasonable to turn to public speech acts to identify these trends.

\section{THE CRISIS DisCOURSE OF CENTRAL BANKERS}

Figure 2 summarizes the results of our quantitative analysis, indicating the relative frequency with which key words and phrases appear in central bankers' speeches over time. We divide our charts into three groups: shock, core, and layers. Shock includes words and phrases associated with the crisis itself (financial crisis, crisis lessons, sovereign debt, and

\footnotetext{
${ }^{5}$ We use software by Benoit et al. (2018) to remove stop words, numbers, and punctions; and to remove inflections from words in order to reduce them to their roots. We use software by Roberts, Stewart, and Tingley (2018) to estimate a Correlated Topic Model (Blei and Lafferty 2007). This model is preferable to alternatives like the Latent Dirichlet Allocation, because it allows for certain topics to appear together more frequently than others. We estimated 20 different models using numbers of topics $(K)$ between 10 and 500 , and we compared the results using four different criteria (exclusivity, semantic coherence, heldout likelihood, and bound). The results show that models tend to improve as $\mathrm{K}$ increases, but with clear diminishing returns after we reach $K \approx 100$. For this reason, we will focus on a model with $K=100$. We also replicated the core analyses of the paper with different numbers of topics, and our substantive conclusions remained unchanged. 85 of the 100 inductively-recovered topics referred to clearly identifiable concepts, a relatively high number which is reassuring, because it suggests that central bankers tend to use similar word combinations to discuss similar issues, and that the topic model picks up relevant topics.
} 
subprime). Core includes those that capture the key elements of the original monetary policy paradigm (price stability, independence, inflation target, credibility, transparency, and communication). Layers include those referring to newer concepts and concerns (financial stability, mandate, macroprudential, and quantitative easing). Underneath the summary charts, we separate out speeches given by central bankers from eurozone and non-eurozone countries in order to capture any disparate effects from the eurozone's dual crises. $^{6}$

Figure 2: Frequency of Key Words and Phrases, 1997-2017 (BIS database)

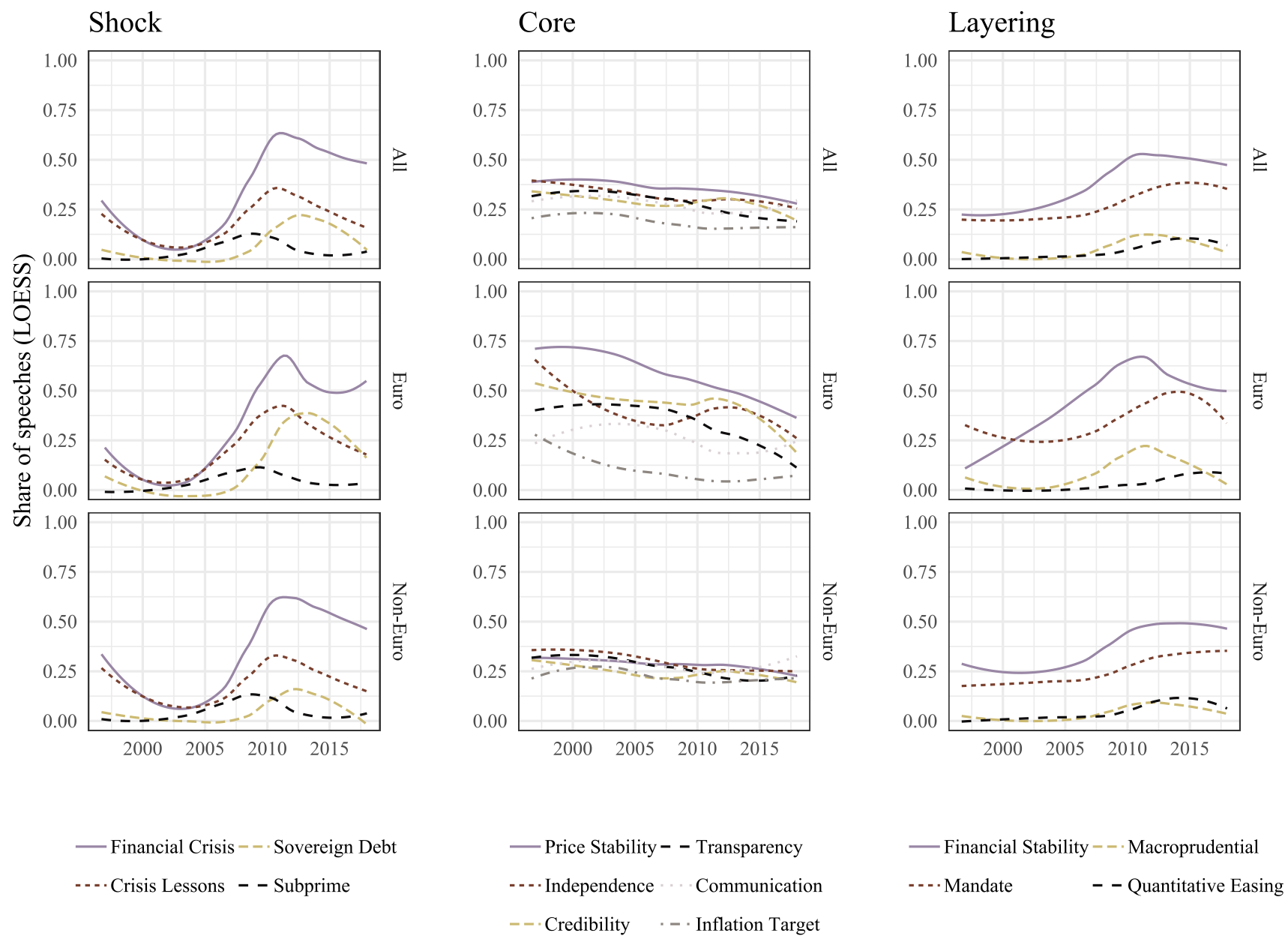

As the Shock charts indicate, central bankers talked extensively about the financial crisis and its lessons in their public speeches; at its height, over $60 \%$ of all speeches referred

\footnotetext{
${ }^{6}$ We extrapolate eurozone membership backwards in time through 1997, as eurozone-centric discussions and concerns predated formal creation and entry.
} 
to the financial crisis while nearly $40 \%$ specifically mentioned both the crisis and lessons. The lesson-drawing peak occurred in 2010 and has gradually receded along with the crisis itself. As expected, the eurozone's Shock chart has an additional, later peak in response to the sovereign debt crisis.

Importantly, this finding is robust to alternative methodological approaches. In Figure 3, we use our topic model to measure the prevalence of a "financial crisis" topic, which captures words such as collapse, crisis, Lehman, and rescue. Higher values on the yaxis indicate that speeches include many words related to financial crises. As we can see, central bankers discussed the financial crises extensively in 1997 (corresponding to the Asian financial crisis) and in 2008-14 (corresponding to the global financial crisis). With this more inductive approach, we can confirm that the financial crisis and lessons for policymaking heavily preoccupied central bankers. While this was particularly true in the immediate aftermath of the global financial crisis, our word count analysis shows that nearly $50 \%$ of all speeches still made reference to the financial crisis a full decade later.

Figure 3: Financial Crisis Topic Prevalance, 1997-2017 (BIS database)

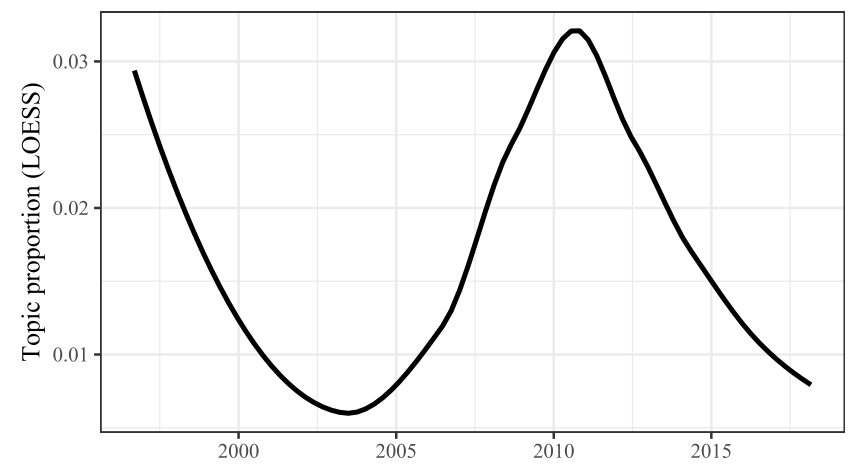

Nevertheless, central bankers' engagement with core elements of the monetary policy paradigm remained remarkably resilient after the crisis. Terms capturing the interrelated Core concepts (price stability, independence, and credibility) and the means to achieve them (inflation targeting, transparency, and communication) reliably appeared in $20-40 \%$ of all speeches across time; looking at the overall trend lines, one would not be able to guess that a major upheaval had occurred in 2007-08 (Figure 2 - Core). Eurozone central bankers, however, did increasingly discuss credibility and independence as the sovereign debt crisis hit.? Topic modeling confirms the especially tight ties among Core concepts, as a

\footnotetext{
7 Other differences in the eurozone's Core patterns reflect in great part: 1) the intense discussions surrounding the ECB's creation and institutionalization as a highly independent central bank with a single price stability mandate, resulting in unusually high Core word/phrase frequencies in the early years of the database (in recent years eurozone Core frequencies have been converging with those of the rest of the world); and 2) the ECB's practice of not using the specific word "target" when referring to its monetary policy, even though it is an inflation-targeting central bank. The ECB instead says, e.g., that it "aims at inflation rates of below, but close to, $2 \%$ over the medium term"

(https://www.ecb.europa.eu/mopo/html/index.en.html).
} 
single highly salient monetary policy topic included the words monetary, objective, independence, policy, stability, and credibility.

Finally, the Layers charts show central bankers' increased post-crisis interest in unconventional monetary policies (represented here by quantitative easing) and macroprudential policy, as well as growing concern with broader financial stability issues and the proper scope of central bank mandates (Figure 2 - Layers). The eurozone breakout chart reveals the especially significant concern with financial stability and the ECB's mandate sparked by the dual crises, as well as a higher-than-average interest in macroprudential policies.

In the next sections, we draw on our qualitative analysis to flesh out these trends, going beyond the frequency of discussion to engage the content. We see that central bankers' initial response to crisis generally fit the expectations of the threat-perception model. Although acknowledging that something had gone gravely wrong, most in the community leapt to defend the core concepts of the pre-crisis monetary policy paradigm. As the ECB and Bundesbank's Jürgen Stark argued in 2010:

Certainly, some aspects of the framework will, in my view, have to survive the crisis. The first aspect is central bank independence... The second aspect is the centrality of price stability for monetary policy. And the third aspect is the importance of transparent

communication. The crisis has not at all discredited these three principles. Together they have formed, and I believe will continue to form, the basis for central banks' credibility and efficiency in contributing to the economic welfare of nations. (r101125f).

While the community continued to defend these principles in the years after the crisis, over time central bankers' responses became more differentiated and involved layering new concepts over the old with an eye towards redeeming and reforming rather than replacing them. We begin with price stability and its policy instruments before turning to independence and transparency. Finally, as per Stark, we tie it all together with a discussion of credibility in post-crisis central banking.

\section{PRICE STABILITY}

Central bankers remained adamant that the crisis had not invalidated the rationale for their price stability mandates. As Stefan Gerlach of the Central Bank of Ireland said, "the earlier consensus that monetary policy should focus on ensuring price stability remains unchanged" (2012, r120301d). Yet at the same time they added a layer to this conviction, saying the crisis taught them that "price stability does not guarantee financial stability." By 2010, central bankers' language on this score had already coalesced around similar versions of the phrase "price stability is a necessary but insufficient condition for financial stability."

\footnotetext{
${ }^{8}$ For example, see Cœure (ECB/France, 2012, r120327b) and Weidmann (Germany, 2015, r150713a).
} 
Forty post-crisis speeches referenced "price stability," "sufficient," and "financial stability" in the same sentence. ${ }^{9}$ As US Federal Reserve chairman Ben Bernanke observed in 2011:

My guess is that the current framework for monetary policy - with innovations, no doubt, to further improve the ability of central banks to communicate with the public - will remain the standard approach, as its benefits in terms of macroeconomic stabilization have been demonstrated. However, central banks are also heeding the broader lesson, that the maintenance of financial stability is an equally critical responsibility. (2011, r111019b).

In this way, central bankers reasserted the primacy of price stability while adding a new concern with financial stability.

The admission that price stability could not guarantee financial stability, as well as the post-crisis difficulty in achieving even price stability through traditional interest-rate policy, opened the door to debate over existing policy instruments and to the introduction of additional ones. As a result, central bankers not only rhetorically embraced macroprudential policies as a way to pursue financial stability (Baker, 2013; Lombardi \& Moschella, 2016; McPhilemy, 2017; Thiemann, 2019), but more importantly for our purposes, they debated the merits of inflation targeting and introduced unconventional monetary policies in their pursuit of price stability..$^{10}$

\section{Inflation Targeting}

The pre-crisis monetary policy paradigm endorsed inflation targeting as the main policy through which to pursue price stability. After the crisis both inflation targeting itself and the proper target level came into question. Bank of Canada governor Mark Carney famously mused about moving to price-level or nominal GDP-level targeting as early as 2009 (e.g., see 2009, r090826a), and a serious debate ensued; the phrases "inflation target" or "inflation targeting" appeared in $51 \%$ of the 997 "crisis lesson" speeches. However, the vast majority of this debate represented a defense of inflation targeting, and even Carney later returned to support for inflation targeting in his public speeches (e.g., UK, 2011, r111215a). As Stephen Poloz put it, "nothing is broken, and the bar for changes to the inflation-targeting agreement will be high ... inflation targeting has served us well, and we remain committed to the concept," (2015, r150226a). The Bank of Mexico's Javier Guzmán Calafell began a lengthy response to outside critics by stating that, "In my opinion, the recent criticisms to

\footnotetext{
9 Interestingly, central bankers in seven speeches before the global financial crisis claimed that this lesson had already been learned, including leading figures such as the Bundesbank's Otmar Issing, the ECB's JeanClaude Trichet, and the Bank of Spain's Jaime Caruana. The first pre-crisis use of this phrasing appeared in 2002 (Backstrom, Sweden, 2002, r021126a) while the last appeared in 2007 (Papademos, ECB/Greece, 2007, r070613d).

10 Although a more detailed discussion of macroprudential policy is beyond the scope of this article, see for example Fischer (US, 2015, r160115a), Panetta (Italy, 2014, r140627c), Constâncio (ECB/Portugal, 2011/14, r140428b and r111006i), Shirakawa (Japan, 2009, r091223), Bini Smaghi (ECB/Italy, 2009, r091019e), and Jordan (Switzerland, 2010, r100924b) on macroprudential policy as the first line of defense in pursuing financial stability.
} 
inflation targeting are quite feeble," (2014, r140827e). Chongsoo Kim of the Bank of Korea noted that, "inflation targeting was suggested in the early 1990s, and not a single country that has adopted this regime has ever given it up," (2014, r140519a). As early as 2009 Lars Svensson argued that, "flexible inflation targeting, applied in the right way and using all the information about financial factors that is relevant for the forecast of inflation and resource utilization at any horizon, remains the best-practice monetary policy before, during, and after the financial crisis," (2009, r090923d; see also 2010, r100920c). ${ }^{11}$ Central bankers with chapters in the book Is Inflation Targeting Dead? (Reichlin \& Baldwin, 2013) responded with a resounding "No!" Even the Reserve Bank of India, an earlier vocal dissenter from the inflation-targeting club (e.g., Subbarao, India, 2009, r100812a), announced an inflation targeting regime in 2015. As Brazil's governor Alexandre Antonio Tombini summed up:

$\mathrm{A}[\mathrm{n}]$... issue that has been the subject of considerable debate is the nature of monetary policy regimes. Before the crisis, there was a strong consensus on inflation targeting (or IT) as the most adequate monetary policy regime, due to its flexibility and transparency... My take on this debate is that, at the end of the day, inflation targeting emerged even stronger from the crisis. (2015, r150612a).

Although inflation targeting in practice has become more flexible since the crisis, the basic belief in inflation targeting as a policy was reinforced for most central bankers - so much so that Australia's Guy Debelle could state confidently in 2018 that "inflation targeting is ... the default framework for monetary policy" around the world (r180417e).

A similar dynamic emerged in discussions on the proper target level itself. Before the crisis, inflation-targeting central banks in OECD countries had converged on $2 \%$ as an appropriate target, with slightly higher targets for emerging market economies. In 2010, IMF chief economist Olivier Blanchard suggested that targets should be raised, perhaps to $4 \%$, in order to give central bankers more policy flexibility during recessions (Blanchard, Dell'Ariccia, \& Mauro, 2010). Central bankers at first wasted no time in denouncing this proposal, with 44 of the "crisis lesson" speeches mentioning Blanchard by name. As the Bank of Canada's John Murray stated:

Some noted economists have recommended raising the inflation target ... This idea has been universally rejected by the central banking community, however, which argues that the costs incurred through lost credibility as well as higher and more uncertain inflation would far outweigh any prospective benefits. Low, stable, and predictable inflation, it is generally agreed, is the most important contribution that central banks can make to the economic well-being of a country. (2010, r100830e)

\footnotetext{
11 See also Bean (UK, 2010, r100901d), Mminele (South Africa, 2012, r120727c), Trairatvorakul (Thailand, 2015, r150128a), Dale (UK, 2013, r131018i) for strong statements in this regard.
} 
German central bankers were particularly outraged by the proposal, with the Bundesbank's Jens Weidmann invoking hyperinflation under the Weimar Republic in his vigorous rejection and repeating the Economist's line that "Asking a central banker to accept higher inflation may seem like asking a cardinal to accept more sin," (2015, r150713a). ${ }^{12}$ South African Gill Marcus responded from the emerging market perspective, noting that "although our inflation target of between 3 and 6 per cent is higher than the advanced economy norm ... our view is that a higher inflation target would merely raise inflation expectations, and actual inflation would then likely increase," (2014, r141103c). ${ }^{13}$ More recently, however, central bankers in the US have returned to Blanchard's proposal with cautious interest, indicating that an intellectual shift may yet be possible. ${ }^{14}$

\section{Unconventional Monetary Policy}

The defense of conservative inflation targeting was accompanied by a significant post-crisis shift in the way central bankers in the advanced industrial democracies set out to meet their targets; central bankers took what they referred to as "extraordinary" means to pursue their ordinary goal of achieving price stability. Glenn Stevens of the Reserve Bank of Australia echoed others in saying that "Some central banks have found themselves doing extraordinary things because of the extraordinary circumstances to which they were required, by their mandates, to respond as best they could" (2015, r150701f). Most notable among these means were quantitative easing (directly buying government or other securities) and negative interest rates (dipping below the zero lower bound).

Central bankers often explicitly framed this choice in terms of the original paradigm and hoped to restore "normalcy" - meaning putting an end to these crisis-era policies - as soon as they deemed it prudent. As the Bank of England's Charles Bean noted, "asset purchases aimed at flattening the yield curve are probably best kept in the locker marked For Emergency Use Only" (2010, r100901d). Central bankers' general discomfort with their post-crisis actions was reflected in their ongoing discussion of "normalization" and planned "exit strategies" from these "unconventional" monetary policies, terms which verbally distanced the policies from the ones that central bankers considered within their usual

\footnotetext{
12 See also, for example, Yellen (US, 2015, r150928g) and Kohn (US, 2010, r100517d); Weidmann (ECB/Germany, 2012/3, r120615h, r130214, and r151005c), Weber (ECB/Germany, 2010/11, r100518a and r110414g), and Bohmler (Germany, 2010, r101123e); Côté (Canada, 2014, r141119c), Carney (Canada, 2011, r111215a) and Poloz (Canada, 2013, r131213c and 2016, r161025e); Jansson (Sweden, 2012, r121016c) and Skingsley (Sweden, 2015, r150604d); Bean (UK, 2010/11, r110720b, r100901d and r100318e); Lowe (Australia, 2010, r100311e); Praet (ECB/Belgium, 2014, r140704d); and Constâncio (ECB/Portugal, 2013, r160113a).

13 For a similar statement, see De Gregorio (Chile, 2010, r100603c).

${ }^{14}$ For example, US Federal Reserve veterans John Williams and Ben Bernanke discussed alternatives at a 2017 Brookings Institution conference. See the event summary at https://www.brookings.edu/events/should-the-fed-stick-with-the-2-percent-inflation-target-or-rethink-it/
} 
remit. Figure 4 presents what we call the central banker discomfort index, which measures the collective prevalence of the words "exit," "unconventional," and "normalization" in central bankers' speeches. As is evident, the concern with exit strategies began immediately in 2008, in tandem with the introduction of quantitative easing. Yet over time, many central bankers have begun to accept that these new instruments may have to remain in their tool kit, albeit in reserve. As such, "normalization" has gradually come to mean not abandoning them entirely, but systematically reducing their use and studying their effects in order to incorporate them into the paradigm.

Figure 4: Central Banker Discomfort Index, 1997-2017 (BIS database)

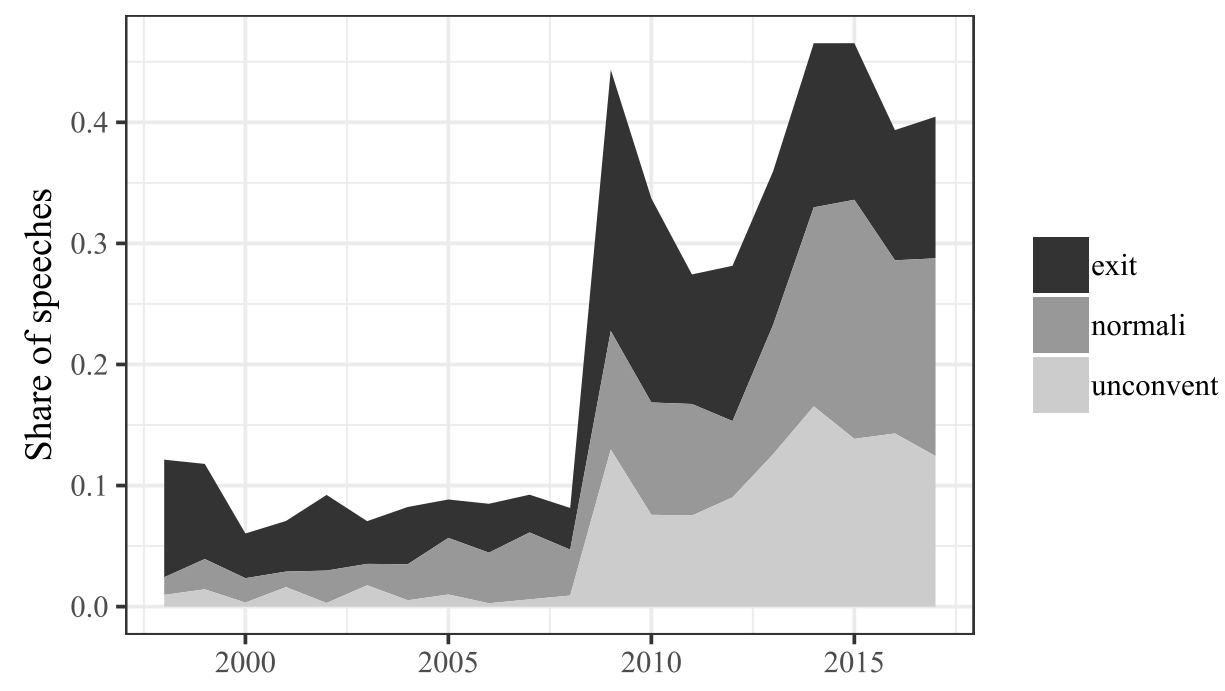

\section{INDEPENDENCE}

Central bankers became protective of their monetary policy independence after the crisis; the word independence appeared in $42 \%$ of "crisis lesson" speeches and consistently in over $25 \%$ of all speeches. Given that independence is an institutional characteristic of the central bank rather than a policy or economic issue-area, the relative frequency with which it came up in public speeches revealed its ongoing importance to the central banking community. ${ }^{15}$

Central bankers defended independence in their speeches with lofty words. The US Federal Reserve's Kevin Warsh entitled his 2010 speech "An Ode to Independence," writing that "Central bank independence is precious ... fierce independence is needed, perhaps now more than ever" (r100401d). Perceived threats to the ECB's monetary policy independence in the wake of its dual crises raised especially strong responses (but see also van Esch \& de Jong, 2013). For example, the Bank of Italy's Salvatore Rossi declared that "It is in the interest of all Europeans that [the ECB's] independence continue to be defended

15 We do not report those results here because of space considerations, but topic modeling revealed a similar temporal pattern for a topic that included words clearly related to central bank independence. 
from within and seen favorably from without" (2014, r141209f), while Erkki Liikanen of the Bank of Finland argued in 2015, "One of the lasting lessons we have learned from the monetary policy experience of the last decades is the value of the independence of central banks ... I am convinced that central bank independence is equally as important in today's environment" (r150203b).

The speeches with a substantive discussion of central bank independence typically also mentioned price stability in close proximity, suggesting the connection central bankers made between these two concepts. In a pattern repeated elsewhere, Barbo Wickman-Parak of the Sveriges Riksbank began her 2013 speech on central bank independence with a caution that "It is so easy to fasten in what one might scientifically term the 'prevailing paradigm' ... one should never be too confident. What seems obvious now may not seem so tomorrow," and then continued six pages later to state confidently that "I believe it is essential not to withdraw the central banks' independence with regard to the task of price stability" (r130521d). Likewise, France's Christian Noyer insisted that "strong, independent and responsible central banks are, more than ever, necessary to price and financial stability" (2012, r121203b).

Central bankers took care to define this independence in relation to their mandate. As the Swiss National Bank's Thomas Jordan argued, "In the long run, a central bank can only pursue an autonomous monetary policy in line with the needs of its country if it is independent... What independence also means, however, is the responsibility to use this freedom strictly within the meaning of the statutory mandate, no matter what the prevailing political climate may be" (2014, r140117a). For this reason, central bankers shared a general concern that adding formal financial stability mandates to their price stability ones had the potential to undermine central bank independence because they would require greater cooperation with other government agencies and more clearly engage overtly political questions of regulation and distribution. ${ }^{16}$ As South Africa's François Groepe observed, "the biggest risk to central bank independence is the possible backlash from being unable to deliver on unreasonable expectations. Central bank mandates have expanded - perhaps appropriately so - but there are limits to what monetary policy was designed to achieve" (2016, r160818a).

Some argued that central banks could maintain monetary policy independence even without independence in regards to financial stability (e.g., Fischer, Israel, 2015, r151109c), while others felt that expanded mandates required expanded independence as well (e.g., Isarescu, Romania, 2016, r160324a). For certain European central bankers, ameliorating the threat meant attempting to erect a "Chinese wall" between monetary and financial stability responsibilities at the ECB (e.g., Bini-Smaghi, Italy, 2011, r110120c; Asmussen, Germany, 2012, r120912c). In sum, central bankers' belief in the importance of monetary policy independence survived the crisis and led to a shared understanding that expanded

${ }^{16}$ For example, see Noyer (France, 2012, r121203b), King (UK, 2013, r130417c), Kiuchi (Japan, 2013, r130319c), Subbarao (India, evolving views - r090915b, r110614b, r110510b r130111c). 
responsibilities could threaten that independence, but engendered disagreement over how best to deal with that threat and what the limits of central bank independence should be.

\section{TRANSPARENCY}

Finally, the global financial crisis reinforced central bankers' belief in transparency and communication as not only necessary to transmit policy signals accurately, but also as the key instruments through which to guarantee their accountability to governments and the public (Blinder, Ehrmann, Fratzscher, De Haan, \& Jansen, 2008; Crowe \& Meade, 2008; Dincer \& Eichengreen, 2013; Moschella \& Pinto, 2019). The BIS database itself is an indicator of this; as Figure 1 shows, central bankers around the world speak about their roles and publicize their speeches more often since the global financial crisis.

Central bankers used the words transparency and communication in over $20 \%$ of speeches every year from 1997 on, and the two words appear together in an auto-generated topic as well. As with other core concepts in the monetary policy paradigm, central bankers became increasingly aware of the value of so-called "open mouth operations" in molding public expectations and building public support at the turn of the 21st century (Guthrie \& Wright, 2000). Central banks experienced what Alan Blinder (2008) dubbed a quiet revolution in central bank transparency and communication, coming to view greater openness and clarity as virtues that would allow the public to better interpret and react to central bank policies, thus enhancing their ability to promote price stability (Demertzis \& Hughes Hallett, 2007; Geraats, 2002). This resulted in many central banks embracing transparency by, for example, making the minutes of their monetary policy meetings more readily available and/or adopting policies such as "forward guidance," in which central bankers used communication tools to indicate the policy directions in which they would be leaning in the medium-term future.

After the crisis, central bankers regularly accompanied their public paeans to independence with a reassurance that, in the words of Klaas Knot of the Netherlands, "independence is sustainable only if it is accompanied by strong accountability and a high level of transparency" (2013, r131017b). Or as the US Federal Reserve's Charles Plosser observed:

Central bank independence is a fundamental tenet of sound central banking and leads to better economic outcomes. But independence must be accompanied by accountability. And accountability is more easily achieved when there is transparency. The public can best hold a central bank accountable when its goals are clearly stated and achievable. (2014, r140115b)

According to central bankers, this gave independent central banks the legitimacy to pursue their price stability mandate. Likewise, pursuing price stability through inflation targeting transparently communicated the central bank's goal and provided a benchmark through which it could be held accountable. Central bankers spoke of an organic relationship among 
these elements of the pre-crisis monetary policy paradigm, with each reinforcing the other and providing a stable foundation for central banking even after the crisis. At the same time, central bankers stretched the original paradigm by more broadly defining and debating key elements (e.g., flexible inflation targeting) and layering new concepts (e.g., financial stability) and tools (e.g., unconventional monetary policy) on top of the old.

\section{CONCLUSION: IN PURSUIT OF CREDIBILITY}

Our quantitative and qualitative text analysis of speeches by central bankers from around the world has demonstrated that central bankers, though shaken profoundly by the global financial crisis, have not rhetorically abandoned the core elements of their pre-crisis monetary policy paradigm. Through a complex pattern of reinforcement, reassessment, and layering, they have instead reconstituted that paradigm in expanded and slightly modified form, albeit at the cost of some dissensus within the community.

Although explaining why central bankers chose this path lies outside the scope of this paper, we close by proposing that central bankers may have moved gradually and incrementally to reshape their pre-crisis monetary policy paradigm in an attempt to preserve that most vital of all central bank attributes: credibility. As Dellepiane (2017) observes, since the crisis "the rhetoric of credibility has been ubiquitous in the framing of policy responses and institutional innovations." Credibility is the code word that central bankers use to describe their combined performative and technical reputations. A public agency's performative reputation refers to its perceived ability to get the job done with competence and efficiency, while its technical reputation refers to the perceived capacity and skill of its staff (D. P. Carpenter \& Krause, 2012). As Carpenter (2010) notes, the different dimensions of an agency's reputation are not necessarily complementary; working to enhance one may damage another.

In the case of central banks, the global financial crisis broke the previous link between central banks' performative and technical reputations. Before the crisis, central banks appeared to perform well as low inflation reigned in the era of the so-called Great Moderation, and central banks earned a strong technical reputation as they invested heavily in the capacity to conduct the inflation-targeting monetary policy that they believed led to this price stability. The crisis simultaneously threatened central bankers' performative and technical reputations, but the solutions to shoring up one seemed at odds with preserving the other.

On the one hand, central bankers' technical expertise lay in traditional monetary policy tools and models, and expanding their repertoire of practice before laying the intellectual groundwork for it risked undermining their technical reputations. Central bankers thus expressed discomfort with branching out into new policy areas and legitimizing new policy tools that fell outside their technical wheelhouse. On the other hand, failing to do so in an environment in which their traditional tools and models had already proven ineffective would doom their inflation-fighting efforts from the start and undermine their performance. Moreover, either option risked reducing their independence: 
expanded tools and mandates would inevitably raise issues of politicization and mission creep, while failure to deliver results on price and increasingly on financial stability would undermine the original rationale for central bank independence.

Under the circumstances, it should not be surprising that in attempting to preserve their credibility central bankers have done their best to avoid making a stark public choice between the two options. By retaining the core of their pre-crisis monetary policy paradigm while at the same time "adding rooms onto the house that [they] love," central bankers may be engaging in a delicate attempt to reforge the previously symbiotic relationship between their performative and technical reputations, and in so doing regain their credibility as autonomous public agencies. More generally, our research suggests that public agents find it easier to innovate after crises when they can frame their innovations as building upon rather than supplanting their most fundamental pre-crisis beliefs. 


\section{REFERENCES}

Baker, A. (2013). The new political economy of the macroprudential ideational shift. New Political Economy, 18(1), 112-139.

Baker, A. (2015). Varieties of economic crisis, varieties of ideational change: How and why financial regulation and macroeconomic policy differ. New Political Economy, 20(3), 342-366.

Balls, E., J Howat and A Stansbury. (2016). 'Central Bank Independence Revisited: After the Financial Crisis, What Should a Model Central Bank Look Like?'. Harvard Kennedy School Mossavar-Rahmani Centre for Business and Government Associate Working Paper No. 67.

Bennani, H. (2015). Dissecting the brains of central bankers: The case of the ECB's Governing Council members on reforms. International Economics, 141, 97-114.

Bennani, H., \& Neuenkirch, M. (2017). The (home) bias of European central bankers: new evidence based on speeches. Applied Economics, 49(11), 1114-1131.

Bennett, C., \& Howlett, M. (1992). The Lessons of Learning: Reconciling Theories of Policy Learning and Policy Change. Policy sciences, 25, 275-294.

Bernanke, B. (2015). The Courage to Act: A Memoir of a Crisis and Its Aftermath. New York: W.W. Norton.

Benoit, Kenneth, Kohei Watanabe, Haiyan Wang, Paul Nulty, Adam Obeng, Stefan Müller, and Akitaka Matsuo. (2018) "quanteda: An R package for the quantitative analysis of textual data”. Journal of Open Source Software. 3(30), 774. https://doi.org/10.21105/joss.00774.

Bholat, D. M., Hansen, S., Santos, P., \& Schonhardt-Bailey, C. (2015). Text mining for central banks. Centre for Central Banking Studies.

Blanchard, O., Dell'Ariccia, G., \& Mauro, P. (2010). Rethinking macroeconomic policy. Journal of Money, Credit and Banking, 42(s1), 199-215.

Blei, D. M., \& Lafferty, J. D. (2007). A correlated topic model of science. The Annals of Applied Statistics, 17-35.

Blei, D. M., Ng, A. Y., \& Jordan, M. I. (2003). Latent dirichlet allocation. Journal of machine Learning research, 3(Jan), 993-1022.

Blinder, A. S. (2008). The Quiet Revolution: central banking goes modern: Yale University Press.

Blinder, A. S., Ehrmann, M., Fratzscher, M., De Haan, J., \& Jansen, D.-J. (2008). Central bank communication and monetary policy: A survey of theory and evidence.

Retrieved from

Blyth, M., \& Matthijs, M. (2017). Black Swans, Lame Ducks, and the mystery of IPE's missing macroeconomy. Review of International Political Economy, 24(2), 203-231.

Boettke, P. J., \& Smith, D. J. (2015). Monetary policy and the quest for robust political economy. 
Boin, A., t Hart, P., \& McConnell, A. (2009). Crisis exploitation: political and policy impacts of framing contests. Journal of European Public Policy, 16(1), 81-106. doi:10.1080/13501760802453221

Boin, A., \& t'Hart, P. (2003). Public leadership in times of crisis: mission impossible? Public Administration Review, 63(5), 544-553.

Borio, C. (2011). Central banking post-crisis: What compass for uncharted waters? : Bank for International Settlements.

Braun, B. (2018). Central bank planning? Unconventional monetary policy and the price of bending the yield curve. In J. Beckert \& R. Bronk (Eds.), Uncertain Futures: Imaginaries, Narratives, and Calculation in the Economy. Oxford: Oxford University Press

Broome, A., \& Seabrooke, L. (2015). Shaping policy curves: Cognitive authority in transnational capacity building. Public Administration, 93(4), 956-972.

Buiter, W. (2006). Rethinking inflation targeting and central bank independence. Paper presented at the Turkish Economic Association Conference, Ankara, September.

Capoccia, G., \& Kelemen, R. D. (2007). The study of critical junctures: Theory, narrative, and counterfactuals in historical institutionalism. World Politics, 59(3), 341-369.

Carpenter, D. (2010). Reputation and power. Organizational Image and Pharmaceutical Regulation at the FDA. Princeton.

Carpenter, D. P., \& Krause, G. A. (2012). Reputation and public administration. Public Administration Review, 72(1), 26-32.

Collier, R. B., \& Collier, D. (2002). Shaping the political arena: Critical junctures, the labor movement, and regime dynamics in Latin America.

Crowe, C., \& Meade, E. E. (2008). Central bank independence and transparency: Evolution and effectiveness. European Journal of Political Economy, 24(4), 763-777.

Davies, H., \& Green, D. (2010). Banking on the future: The fall and rise of central banking: Princeton University Press.

Dellepiane, S. (2017). Credibility Narratives and the Rethinking of Central Banking during the Great Recession. Paper presented at the Workshop on "Independent Agencies Under Stress: Central Banks in the Aftermath of the Great Recession”, Scuola Normale Superiore, Firenze.

Demertzis, M., \& Hughes Hallett, A. (2007). Central bank transparency in theory and practice. Journal of Macroeconomics, 29(4), 760-789.

Dincer, N. N., \& Eichengreen, B. (2013). Central Bank Transparency and Independence: Updates and New Measures. Bank of Korea Working Paper, 2013(21).

Dunlop, C. A., \& Radaelli, C. M. (2013). Systematising policy learning: From monolith to dimensions. Political Studies, 61(3), 599-619.

Dyson, S. B., \& Raleigh, A. L. (2014). Public and private beliefs of political leaders: Saddam Hussein in front of a crowd and behind closed doors. Research \& Politics, 1(1).

Fontan, C., Claveau, F., \& Dietsch, P. (2016). Central banking and inequalities: Taking off the blinders. Politics, Philosophy \& Economics, 15(4), 319-357. 
Geraats, P. M. (2002). Central Bank Transparency*. The economic journal, 112(483), F532F565.

Golub, S., Kaya, A., \& Reay, M. (2015). What were they thinking? The Federal Reserve in the run-up to the 2008 financial crisis. Review of International Political Economy, 22(4), 657-692.

Goodfriend, M. (2007). How the world achieved consensus on monetary policy. Journal of Economic Perspectives, 21(4), 47-68.

Grimmer, Justin, and Brandon M Stewart. (2013). “Text as Data: The Promise and Pitfalls of Automatic Content Analysis Methods for Political Texts.” Political Analysis, 21(3), 267-297.

Guthrie, G., \& Wright, J. (2000). Open mouth operations. Journal of Monetary Economics, 46(2), 489-516.

Hall, P. (1993). Policy Paradigms, Social Learning, and the State. Comparative Politics, 25(3), 275-296.

Johnson, J. (2016). Priests of Prosperity: How Central Bankers Transformed the Postcommunist World: Cornell University Press.

Krampf, A. (2016). From transparency to ambiguity: the impact of the ECB's unconventional policies on the EMU. Journal of European Integration, 38(4), 455471.

Lombardi, D., \& Moschella, M. (2016). The symbolic politics of delegation: macroprudential policy and independent regulatory authorities. New Political Economy, 22(1), 92-108.

McPhilemy, S. (2017). Learning from disasters? Central banks, financial stability policies and theories of risk-management. Paper presented at the Workshop on "Independent Agencies Under Stress: Central Banks in the Aftermath of the Great Recession", Scuola Normale Superiore, Firenze.

Mohan, R. (2013). Need for Thought Diversity to Combat Group-Think in Central Banking Think Tank 20: The G-20 and Central Banks in the New World of Unconventional Monetary Policy. Washington, DC: Brookings Institution.

Moschella, M., \& Pinto, L. (2019). Managing central banks' reputation through communication: Policy reversals and the Federal Reserve talk. Public Administration.

Princen, S., \& Van Esch, F. (2016). Paradigm formation and paradigm change in the EU's Stability and Growth Pact. European Political Science Review, 8(3), 355-375.

Rajan, R. (2017). I Do What I Do. India: Harper Business.

Reichlin, L., \& Baldwin, R. E. (2013). Is Inflation Targeting Dead?: Central Banking After the Crisis: CEPR.

Renshon, J. (2009). When public statements reveal private beliefs: Assessing operational codes at a distance. Political Psychology, 30(4), 649-661.

Roberts, M, Steward, M, Tingley, D. (2018). stm: An R Package for the Structural Topic Model. http://www.structuraltopicmodel.com 
Rose, R. (1993). Lesson-drawing in public policy: A guide to learning across time and space (Vol. 91): Chatham House Publishers Chatham, NJ.

Sabatier, P. A. (1998). The advocacy coalition framework: revisions and relevance for Europe. Journal of European Public Policy, 5(1), 98-130. doi:10.1080/13501768880000051

Schonhardt-Bailey, C. (2013). Deliberating American monetary policy: a textual analysis: MIT Press.

Seabrooke, L., \& Tsingou, E. (2014). Distinctions, affiliations, and professional knowledge in financial reform expert groups. Journal of European Public Policy, 21(3), 389-407.

Stern, E. (1997). Crisis and learning: A conceptual balance sheet. Journal of contingencies and crisis management, 5(2), 69-86.

Stern, E., \& Sundelius, B. (1997). Sweden's twin monetary crises of 1992: Rigidity and learning in crisis decision making. Journal of contingencies and crisis management, 5(1), 32-48.

Streeck, W., \& Thelen, K. A. (2005). Beyond continuity: Institutional change in advanced political economies: Oxford University Press.

Thiemann, M. (2019). Is Resilience Enough? The Macroprudential Reform Agenda. Public Administration.

van Esch, F., \& de Jong, E. (2013). Institutionalisation without internalisation. The cultural dimension of French-German conflicts on European Central Bank independence. International Economics and Economic Policy, 10(4), 631-648.

van Esch, F., \& de Jong, E. (2017). National culture trumps EU socialization: the European central bankers' views of the euro crisis. Journal of European Public Policy, 1-19. 